\title{
Kontaminasi Bakteri Coliform pada Saus Siomai dari Pedagang Area Kampus di Surakarta
}

\author{
Liss Dyah Dewi Arini* dan Rahaju Muljo Wulandari \\ APIKES Citra Medika Surakarta \\ *Corresponding author: leeansz_fortune@yahoo.com
}

Contamination of Coliform Bacteria from Seller in Surakarta's University Area

\begin{abstract}
ABSTRAK
Siomai merupakan salah satu makanan pokok yang menggunakan bahan pelengkap (tambahan) makanan berupa saus. Pada saat sekarang ini banyak siomai yang dijual dengan menggunakan sepeda ontel yang ditaruh di bagian belakang sepeda. Akan tetapi dalam kenyataannya kebersihan dari siomai sering juga terabaikan salah satunya karena banyaknya udara dan debu yang masuk ke makanan siomai. Penelitian ini mempunyai tujuan utuuk menguji adanya cemaran bakteri Coliform yang terdapat pada olahan saus yang dijual sebagai pelengkap makanan pada siomai dan mengidentifikasi adanya kandungan bakteri Escherichia coli yang terdapat pada olahan saus yang dijual sebagai pelengkap makanan siomai. Metode penelitian ini adalah penelitian survey lapangan dengan pengambilan sampel secara acak dan deskriptif untuk mengetahui keberadaan bakteri Coliform pada beberapa produk olahan saus yang terdapat pada makanan siomai. Pengambilan sampel penelitian dilakukan mengambil 10 sampel olahan saus dari makanan siomai yang ada di area kampus di Surakarta. Pemeriksaan bakteri Coliform dilakukan di Laboratorium Biologi UNS, Surakarta dengan uji most probable number (MPN), uji Escherichia coli dan pewarnaan gram. Dari uji Most Probable Number melalui uji praduga dan penegasan sampel uji coba menunjukkan hasil positif Coliform, dari hasil pewarnaan gram bakteri yang ditemukan termasuk ke dalam golongan bakteri gram negatif dan dari hasil uji biokimia bakteri-bakteri yang ditemukan pada sampel termasuk spesies Enterobacter dan Escherichia coli. Hasil pengujian yang didapat dari semua uji tidak memenuhi syarat yang telah ditetapkan dalam SNI 01-3546-2004 tentang batas maksimum Angka Lempeng Total (ALT) pada saus tomat adalah $2 \times 10^{2}$ koloni/g sedangkan menurut Peraturan Kepala Badan Pengawas Obat dan Makanan Republik Indonesia nomor HK. 00.06.1.52.401, batas maksimum Most Probable Number (MPN) Coliform pada saus tomat adalah $100 \mathrm{koloni} / \mathrm{g}$.
\end{abstract}

Kata kunci : olahan saus siomai, most probable number, uji biokimia, pewarnaan gram, coliform

\section{ABSTRACT}

Siomai is one food that use complementary materials (additional) that is sauce. At the present time, siomai sold bicycle that was placed on the back of bicycle. But in the reality, the siomai becomes less clean because of the amount of dust and dirty air entered into the siomai, and often this problem is ignored. This research have a goal to test the existence of Coliform bacteria contaminationon sauce that sold for complementary food especially for siomai, and to identify the content of Escherichia coli bacteria that found in sauce preparations that sold for complementary siomai.This research method is a survey field research with random sampling and descriptive to know the existence of Coliform bacteria in some of the processed products of sauce contained in siomai food. Sampling for this research is done by taking 10 sample sauce from siomai food that's all around campus in Surakarta. Coliform bacterial examination was performed at Biology Laboratory of UNS, Surakarta with the most probable number (MPN) test, Escherichia coli test and gram staining. From the test of Most Probable Number through test of presumption and confirmation of test sample showed positive result of Coliform, from the result of gram staining of bacteria found belonging to class of gram negative bacteria and from biochemical test result of bacteria found in samples including Enterobacter species and Escherichia coli .Test results obtained from all tests do not meet the requirements specified in SNI 01-3546-2004 about the maximum number of total plates while according to the Regulation of the Head of the Food and Drugs Agency of the Republic of Indonesia HK number. 00.06.1.52.401, the maximum limit of most probable number (MPN) coliform in tomato sauce is 100 coloni/g.

Keywords: processed siomai sauce, most probable number, biochemical test, gram stain, coliform

\section{PENDAHULUAN}

Makanan adalah bahan-bahan yang dima- kan setiap hari untuk memenuhi kebutuhan bagi pemeliharaan, pertumbuhan, kerja dan peng- 
gantian sel tubuh yang rusak (Sugianto, 2012). Namun pangan juga dapat sebagai sarana penggangu kesehatan bagi manusia karena pangan dapat terkontaminasi oleh cemaran fisik, kimia maupun mikrobia. Makanan berfungsi untuk memelihara proses tubuh dalam pertumbuhan atau perkembangan serta mengganti jaringan tubuh yang rusak, memperoleh energi untuk melakukan aktivitas sehari-hari, mengatur metabolisme dan berbagai keseimbangan air, mineral, dan cairan tubuh yang lain, juga berperan di dalam mekanisme pertahanan tubuh terhadap berbagai penyakit (Notoatmodjo, 2003). Akan tetapi makanan juga sering terkontaminasi oleh kontaminan kimia dan kontaminan biologi.

Salah satu kontaminan biologi yang paling sering dijumpai pada makanan adalah bakteri golongan Coliform yaitu Escherichia coli. Echerichia coli berasal dari tinja manusia dan hewan, tertular ke dalam makanan karena perilaku penjamah yang tidak higienis, pencucian peralatan yang tidak bersih, kesehatan para pengolah dan penjamah makanan serta penggunaan air pencuci yang mengandung coliform, E. coli, dan faecal coliform (Susanna dan Hartono, 2003).

Kontaminasi bakteri patogen pada makanan dan minuman dapat menyebabkan berbagai macam penyakit diantaranya typhoid, diare, keracunan makanan dan lain sebagainya (Siagian, 2002). Penyakit-penyakit ini akan lebih mudah menjangkiti orang yang mengalami penurunan daya tahan tubuh karena faktor dari dalam (intrinsik) maupun dari luar (ekstrinsik). Oleh karena itu, untuk menjamin kesehatan dan keselamatan konsumen, harus dilakukan pemeriksaan laboratorium bakteriologik secara berkala (Lesmana, 2003).

Saus yang seharusnya mengandung gizi dan vitamin yang baik untuk tubuh yang didapat dari buah tomat, cabai dan bumbu-bumbu serta rempah-rempah yang di gunakan, dengan pengolahan yang sehat dan benar tanpa menam- bahkan zat-zat berbahaya tapi pada olahan saus yang dijual secara bebas, yang berlabel maupun tidak berlabel, harga mahal, standar, hingga harga/kg, menambahkan berbagai zat berbahaya di dalamnya dengan cara pengolahannya yang sangat menjijikan penggunaan pepaya busuk berbelatung, kulit singkong yang sudah busuk juga serta penggunaan zat pengawet, MSG berlebihan, zat pewarna tekstil, boraks dan formalin. Dan saus-saus yang tercemar mikroba yaitu Coliform, S. aureus, dan kapang berdam-pak buruk bagi kesehatan tubuh masyarakat yang mengkonsumsinya (Karlah, et al., 2014).

\section{Bahan Makanan \\ Bahan Makanan dan Siomai}

Bahan makanan merupakan kebutuhan manusia yang sangat mendasar karena berpengaruh terhadap eksistensi dan ketahanan hidup manusia. Pangan dalam UU RI No. 7 tahun 1996 diartikan sebagai segala sesuatu yang berasal dari sumber hayati dan air, baik yang diolah maupun tidak diolah, yang diperuntukkan sebagaimakanan atau minuman bagi konsumsi manusia, termasuk bahan tambagan pangan, bahan baku pangan danbahan lain yang digunakan dalam proses penyiapan, pengolahan dan atau pembuatan makanan atau minuman (Kartika et al., 2004).

Saus tomat adalah cairan kental (pasta) yang terbuat dari bubur buah berwarna menarik (biasanya merah), mempunyai aroma dan rasa yang merangsang. Walaupun mengandung air dalam jumlah besar, saus mempunyai daya simpan panjang karena mengandung asam, gula, garam dan seringkali diberi pengawet. Saus tomat dibuat dari campuran bubur buah tomat dan bumbu-bumbu. Pasta ini berwarna merah muda sesuai dengan warna tomat yang digunakan (Imelda, 2009).

\section{Gangguan Kesehatan Akibat Bahan makanan}

Bahan pangan dapat bertindak sebagai 
perantara atau substrat untuk tumbuhnya mikroorganisme yang bersifat patogenik terhadap manusia. Penyakitmenular yang cukup berbahaya seperti tipes, kolera, disentri, $\mathrm{TBC}$, poliomilitis dengan mudah disebarkan melalui bahan pangan. Sebagai akibat dari meningkatnya perjalanan dan perdagangan pangan secara internasional, maka penyakit yang disebabkan bahan pangan dari mikroorganisme telah menjadi perhatian utama dunia(Djaja, 2003).

Makanan tidak saja bermanfaat bagi manusia, tetapi juga sangat baik untuk pertumbuhan mikroba yang patogen. Oleh karena itu, untuk mendapat keuntungan yang maksimum dari makanan, maka sanitasi makanan harus dijaga. Gangguan kesehatan yang dapat terjadi akibat makanan dapat dikelompokkan menjadi keracunan makanan dan penyakit bawaan (Siahaya et al., 2016).

\section{a. Keracunan Bahan Makanan}

Keracunan, secara spesifik diartikan sebagai keadaan yang menimbulkan gangguan gastrointestinal (GI) yang mendadak, dalam waktu 2-40 jam setelah makan dengan menimbulkan gejala muntah-berak, dapat bertahan 1-2 hari atau 7 hari atau lebih.

b. Penyakit Bawaan Bahan Makanan

Bahan makanan yang beracun (asli) seperti tanaman yang mengandung $\mathrm{HCN}$, asam oxalate dan fluor organic (singkong, caladium, dieffenbachia, poinsettia, philodendron); berbagai jenis jamur Amanita, Helvella; pembentuk mycotoxin: Aspergillus flavus, Penicillium, dan Fusarium; algae, seperti Pyrrophyceae, Cyanophyceae, Chrysophyceae; hewan, seperti invertebrata (dinoflagelata, anemones, starfish, sea cucumber), vertebrata (balloon fishes, fugu fishes, hati hiu) dan mamalia.

c. Diare

Penyakit diaremerupakan salah satu penyakit berbasis lingkungan. Penyakit diare masih merupakan masalah kesehatan terbesar di Indonesia karena masih buruknya kondisi sanitasi dasar, lingkungan fisik maupun rendahnya perilaku masyarakat untuk hidup bersih dan sehat. Hal ini berkaitan dengan faktor makanan, imunitas terhadap infeksi dan ketergantungan psikologi.

Diare adalah buang air besar (defekasi) dengan tinja berbentuk cair atau setengah cair (setengah padat), kandungan air tinja lebih banyak dari biasanya lebih dari $200 \mathrm{~g}$ atau $200 \mathrm{ml} / 24 \mathrm{jam}$. Diare infeksi dapat disebabkan Virus, Bakteri, dan Parasit. Diare akut sampai saat ini masih merupakan masalah kesehatan, tidak saja di negara berkembang tetapi juga di negara maju. Penyakit diare masih sering menimbulkan KLB (Kejadian Luar Biasa) dengan penderita yang banyak dalam waktu yang singkat. Tingginya kejadian diare disebabkan karena foodborne infections dan waterborne infections yang disebabkan bakteri Salmonella spp, Campylobacter jejuni, Stafilococcus aureus, Bacillus cereus, Clostridium perfringens dan Enterohemorrhagic Escherichia coli (EHEC).

\section{d. Kontaminasi Mikroba}

Makanan juga dapat terkontaminasi oleh mikroba. Beberapa mikroba pembuat racun baik exotoxin maupun endotoxin, adalah yang tergolong Salmonella, Staphylococcus, Clostridium, Bacillus cocovenans, Bacillus cereus.

\section{Kontaminasi Mikroba}

Makanan juga dapat terkontaminasi oleh mikroba. Beberapa mikroba pembuat racun baik exotoxin maupun endotoxin, adalah yang tergolong Salmonella, Staphylococcus, Clostridium, Bacillus cocovenans, Bacillus cereus (Kusumaningsih, 2010).

\section{Uji Most Probable Number (MPN) Coliform}

MPN adalah metode pemeriksaan air yang dilakukan untuk mengetahui kontaminasi akibat bakteri Coliform dan Coli tinja. Peng- 
amatan sampel yang positif dapat dilihat dengan mengamati adanya kekeruhan dan gelembung gas pada sampel (Sunardi, 2014).

\section{Uji Escherichia coli}

Empat tahap analisis untuk pengujian Escherichia coli adalah Uji Pendugaan dengan metode MPN (most probable number), Uji penguat pada medium selektif, Uji lengkap dengan medium lactose broth, serta Uji Identifikasi denganmelakukan reaksi IMViC (indol, methyl red, Vogues-Praskauer, dan citrate). Jadi untuk dapat menyimpulkan E. coli berada pada air atau makanan diperlukan seluruh tahapan pengujian di atas. Apabila dikehendaki untuk mengetahui serotipe dari $E$. coli yang diperoleh untuk memastikan apakah E.coli tersebut patogen atau bukan maka dapat dilakukan uji serologi. Meskipun demikian, beberapa serotipe patogen tertentu seperti O157:H7 yang ganas tidak dapat diuji langsung dengan pengujian 4 tahap ini dan memerlukan pendekatan analisis khusus sejak awal (Cut Nuria, 2009).

\section{Pewarnaan Gram}

Pewarnaan gram ini bertujuan untuk mlihat bakteri bersifat gram positif atau negatif dan bentuknya. Pewarnaan Gram atau metode Gram adalah suatu metode empiris untuk membedakan spesies bakteri menjadi dua kelompok besar, yakni gram positif dan gram negatif, berdasarkan sifat kimia dan fisik dinding sel mereka. Metode ini diberi nama berdasarkan penemunya, ilmuwan Denmark Hans Christian Gram (1853-1938) yang mengem-bangkan teknik ini pada tahun 1884 untuk membedakan antara pneumokokus dan bakteri Klebsiella pneumonia (Lestari, 2012).

Pada uji pewarnaan Gram, suatu pewarna penimbal (counterstain) ditambahkan setelah metil ungu, yang membuat semua bakteri gram negatif menjadi berwarna merah atau merah muda. Pengujian ini berguna untuk mengkla- sifikasikan kedua tipe bakteri ini berdasarkan perbedaan struktur dinding sel mereka (Lestari, 2012).

\section{METODE PENELITIAN}

\section{Alat dan Bahan}

Alat

Autoclave All American No.75X, Laminar Air Flow OMRON H3BA, Memmert Modell 200 incubator, Microscoph Olympus CX21, Adam Pgw 1502i Precision Balance, Cimarec Hotplate, Brand Micropipette, Lemari Pendingin, Jarum Ose, Spritus, bule tip, Kaca Preparat Sail Brand, Kacapenutup Sailing Boat dan alat-alat gelas Pyrex.

\section{Bahan}

Natrium Clorida $(\mathrm{NaCl})$, Lactose Broth (LB) Merck, aquadest, Briliant Green Lactose Bile 2\% (BGLB) Broth, Eosin Methylene Blue Agar (EMBA) HIMEDIA, Nutrient Agar (NA) Merck, Kliger Iron Agar (KIA), Sulfida, Indol and Motility (SIM), Simmons Citrate Agar, Lysin Iron Agar (LIA), Kristal Violet, Lugol, Alkohol 96\% OneMed dan Safranin.

\section{Cara Kerja}

\section{Pengujian Angka Lempeng Total (ALT)}

Sampel dipipet sebanyak 25,0 $\mathrm{ml}$ ke dalam erlenmeyer yang telah berisi $225 \mathrm{ml}$ larutan pengencer Natrium Clorida $(\mathrm{NaCl})$ dan dikocok sampai homogen. Selanjutnya dilakukan pengenceran secara serial sehingga didapatkan yang sesuai. Dari masing-masing hasil pengenceran sampel dipipet $1,0 \mathrm{ml}$ ke dalam cawan petri steril, kemudian dituangkan 15-20 ml media Plate Count Agar (PCA), yang telah dicairkan dan didinginkan hingga temperaturnya $45^{\circ} \mathrm{C}$ (Karlah, 2014).

Percobaan dilakukan secara triplo dan disertakan cawan petri yang mengandung media dan larutan pengencer yang tidak mengandung sampel sebagai kontrol uji (blanko). Setelah media membeku, inkubasi cawan petri pada 
suhu $37^{\circ} \mathrm{C}$ selama 24 jam dengan posisi terbalik. Dihitung koloni yang tumbuh pada setiap cawan petri. Angka total bakteri dalam 1 gram sampel adalah dengan mengalikan jumlah rata-rata koloni pada cawan petri dengan faktor pengenceran yang digunakan (Karlah, 2014).

\section{Pengujian Most Probable Number (MPN) Coliform}

Pengujian MPN dilakukan dua tahap, yaitu Uji Praduga (Presumtif Test) yang kemudian dilanjutkan dengna Uji Penegasan (Confirmative Test).

\section{Uji Praduga}

Ditimbang 25 gram sampel kemudian ditambahkan $225 \mathrm{ml}$ Lactose Broth (LB) Merck dan dikocok homogen hingga diperoleh suspensi dengan pengenceran 10-1. Disiapkan dua tabung reaksi masing-masing berisi $9 \mathrm{ml}$ LB. Dari hasil homogenisasi pada penyiapan sampel dipipet $1 \mathrm{ml}$ pengenceran $10^{-1} \mathrm{ke}$ dalam tabung LB pertama hingga diperoleh suspensi dengan pengenceran $10^{-2}$ dan dikocok sampai homogen kemudian dibuat pengenceran hingga $10^{-3}$ (Karlah, 2014).

Untuk setiap pengenceran disiapkan 3 tabung reaksi berisi $9 \mathrm{ml}$ Lactose Broth (LB) yang dilengkapi tabung durham kedalam tiap tabung dari masing-masing seri dimasukkan 1 $\mathrm{ml}$ suspensi pengenceran. Diinkubasi pada suhu $35-37^{\circ} \mathrm{C}$ selama $24-48$ jam. Setelah 24 jam dicatat dan diamati perubahan warna biakan dan adanya gas yang terbentuk di dalam tiap tabung. Kemudian untuk tabung yang tidak membentuk gas diinkubasi dilanjutkan hingga 48 jam dan dicatat tabung-tabung yang menunjukkan uji positif (warna biakan menjadi kuning dan ada gas dalam tabung durham) (Karlah, 2014).

2. Uji Penegasan

Biakan tabung yang menunjukkan uji praduga positif dipindahkan satu sengkelit ke dalam tabung reaksi berisi $10 \mathrm{ml}$ Briliant Green Lactose Bile 2\% (BGLB) Broth yang telah dilengkapi tabung durham. Seluruh tabung diikubasi pada suhu $37^{\circ} \mathrm{C}$ selama 24-48 jam. Dilakukan pengamatan adanyapembentukan gas. Pernyataan hasil uji MPN Coliform ini yaitu jumlah tabung yang positif dicatat dan dirujuk pada tabel MPN. Angka yang diperoleh menyatakan jumlah bakteri coliform dalam tiap gram/tiap ml sampel yang diuji (Karlah, 2014).

\section{Identifikasi Escherichia Coli}

Masing-masing biakan positif pada uji konfirmasi bakteri coliform, diambil satu sengkelit dan diinokulasikan pada media Eosin Methylene Blue Agar (EMBA), dan diinkubasi pada suhu $37^{\circ} \mathrm{C}$ selama 24 jam (Imelda, 2009). Dipilih koloni warna hijau dengan kilap logam dan bintik biru kehijauan dari media EMBA dan digoreskan pada media miring Nutrient Agar (NA). Setelah diinkubasi pada suhu $37^{\circ} \mathrm{C}$ selama 24 jam selanjutnya dilakukan uji biokimia untuk identifikasi Escherichia coli dengan uji IMViC (Indol, Methyl Red, VogesProskauer, dan Citrate) (Wang, 2011).

\section{Pewarnaan Gram Bakteri}

Biakan media miring NA pada uji Eschericia coli dan diinkubasi selama 24 jam pada suhu $37^{\circ} \mathrm{C}$. Secara aseptis diambil 1 ose sampel diletakkan pada masing-masing kaca preparat kemudian sampel dipanaskan diatas api Bunsen hingga terfiksasi. Satu tetes kristal violet diteteskan di atas kaca preparat tersebut kemudian didiamkan selama 30 detik. Setelah itu, kaca preparat dibilas dengan aquades (Lestari, 2012).

Larutan Lugol diteteskan di atas kaca preparat kemudian didiamkan selama 1 menit. Setelah itu, kaca preparat dibilas dengan aquades. Kemudian diteteskan etanol 95\% di atas kaca preparat kemudian didiamkan selama 30 detik. Setelah itu, kaca preparat dibilas dengan aquades mengalir hingga warnanya hilang. Teteskan 1 tetes safranin di atas kaca preparat kemudian didiamkan selama 1 menit. Setelah itu, kaca preparat dibilas dengan 
aquades mengalir. Setelah pembilasan terakhir, kaca preparat dikeringkan dan diamati di bawah mikroskop (Lestari, 2012).

\section{Uji Biokimia}

Uji Biokiimia dilakukan dengan menggunakan media KIA, SIM, LIA dan Citrate. Uji Biokimia dilakukan dengan cara sebagai berikut

1) Mengambil Bakteri

a) Mensterilkan tangan menggunakan sabun anti septik.

b) Mensterilkan jarum ose loop dan jarum ose needle dengan cara dipanaskan di atas api bunsen sampai ujung jarum ose needle memerah.

c) Mengambil sampel bakteri.

2) Medium SIM

a) Mensterilkan jarum needle dengan cara memfiksasi ujungnya.

b) Mengambil tabung yang berisi bakteri dan mensterilkan mulut tabung dengan menggunakan api bunsen.

c) Mengambil bakteri dengan cara memasukkan jarum needle ke dalam tabung yang berisi sampel bakteri.

d) Mengambil tabung reaksi berisi medium SIM, dan mensterilkan mulut tabung dengan menggunakan api bunsen.

e) Memasukkan bakteri ke medium SIM dengan cara inokulasi yaitu jarum tegak menusuk media sampai menembus bawah tabung.

f) Mensterilkan mulut tabung kembali dengan menggunakan api bunsen lalu menutup mulut tabung dengan kapas.

3) Medium KIA

a) Mensterilkan jarum needle dengan cara mengfiksasi ujungnya.

b) Mengambil tabung yang berisi bakteri dan mensterilkan mulut tabung dengan menggunakan api bunsen.

c) Mengambil bakteri dengan cara memasukkan jarum needle ke dalam tabung yang berisi sampel bakteri. d) Mengambil tabung reaksi berisi medium KIA, kemudian mensterilkan mulut tabung dengan mengagunakan api bunsen.

e) Memasukkan bakteri ke medium dengan cara memiringkan jarum needle sampai menyentuh bagian pinggir dari dasar tabung.

f) Mensterilkan mulut tabung kembali dengan menggunakan api bunsen lalu menutup mulut tabung dengan kapas.

4) Medium LIA

a) Mensterilkan jarum needle dengan cara mengfiksasi ujungnya.

b) Mengambil tabung yang berisi bakteri dan mensterilkan mulut tabung dengan menggunakan api bunsen.

c) Mengambil bakteri dengan cara memasukkan jarum needle ke dalam tabung yang berisi sampel bakteri.

d) Mengambil tabung reaksi berisi medium LIA, kemudian mensterilkan mulut tabung dengan menggunakan api bunsen.

e) Memasukkan bakteri ke medium dengan cara memiringkan jarum needle sampai menyentuh bagian pinggir dari dasar tabung.

f) Mensterilkan mulut tabung kembali dengan menggunakan api bunsen lalu menutup mulut tabung dengan kapas.

5) Medium Simmon Citrate

a) Mensterilkan jarum ose dengan cara memfiksasi ujungnya.

b) Mengambil tabung yang berisi bakteri dan mensterilkan mulut tabung dengan menggunakan api bunsen.

c) Mengambil bakteri dengan cara memasukkanj arum ose ke dalam tabung yang berisi sampel bakteri.

d) Mengambil tabung reaksi berisi medium simmon citrate, kemudian mensterilkan mulut tabung dengan menggunakan api bunsen.

e) Memasukkan bakteri ke medium dengan cara hanya dioleskan di permukaan tanpa ditusuk. 
f)Mensterilkan mulut tabung kembali dengan menggunakan api bunsen lalu menutup mulut tabung dengan kapas.

\section{Tempat dan Waktu Penelitian}

Penelitian ini dilaksanakan di UPT Laboratorium Terpadu Universitas Sebelas Maret Surakarta. Penelitian ini dilaksanakan pada bulan Juli-Agustus 2017.

\section{Objek Penelitian}

Obyek penelitian adalah tujuh sampel saus siomai yang didapatkan dari penjual siomai keliling yang ada di kampus di area Surakarta yang diambil secara acak (random sampling).

\section{Variabel Penelitian}

Variabel-variabel dalam penelitian ini meliputi:

1. Variabel Bebas

Variabel bebas yang digunakan dalam penelitian ini adalah pengenceran sampel saus yaitu peng-enceran $10^{-1}, 10^{-2}, 10^{-3}$.

2. Variabel Terikat

Variabel terikat dalam penelitian ini adalah jumlah koloni bakteri dan jenis bakteri.

3. Variabel Terkendali

Variabel terkendali dalam penelitian ini adalah variabel yang diusahakan sama untuk setiap perla-kuan meliputi suhu inkubasi, waktu inkubasi, dan jenis media.

\section{Cara Pengumpulan Data Analisis Data}

Data yang diperoleh dianalisis dengan menggunakan:

Uji Most Probable Number

\section{1) Uji Praduga}

Hasil positif ditunjukkan dengan kultur bakteri pada tabung reaksi di dalam tabung durham terdapat ruang kosong yang berisi udara yang panjangnya minimal ada;ah sepertiga panjang tabung durham (Karlah et al., 2014).

2) Uji penegasan
Hasil positif ditunjukkan dengan kultur bakteri pada tabung reaksi di dalam tabung durham terdapat ruang kosong yang berisi udara yang panjangnya minimal ada;ah sepertiga panjang tabung durham (Karlah et al., 2014).

\section{Uji Escherichia coli}

Hasil positif ditunjukkan dengan kultur bakteri pada media EMBA berwarna hijau metalik (Karlah et al., 2014).

\section{Pewarnaan Gram}

Hasil positif ditunjukkan dengan pengamatan preparat dengan pewarnaan safranin dan kristal violet di bawah mikroskop, bekteri tampak berwarna merah (bakteri gram negatif) (Karlah et al., 2014).

Uji Biokimia

Hasil posotif Escherichia coli ditunjukkan dengan uji KIA muncul warna merah(positif mengandung Indol) pada kultur bakteri dan positif Coliform jika pada uji KIA tidak ada sulfide (tidak ada warna hitam pada kultur bakteri) dan pada uji SIM minimal terdapat motilitas atau pergerakan dari bakteri. Untuk identifikasi bakteri dengan uji biokimia KIA, SIM, LIA dan Citrate yang merupakan media penentu identifikasi bakteri adalah pada uji KIA dan SIM, sedangkan uji LIA dan Citrat sifatnya memperkuat hasil uji KIA dan SIM (Laboratorium Mikrobiologi USB, 2017).

\section{HASIL}

Hasil penelitian disajikan pada tabel I (Hasil MPN Coliform Uji Praduga Pada Saus Siomai), tabel 2 (Hasil MPN Coliform Uji Penegasan Pada Saus Siomai ), tabel 3 (Hasil Identifikasi Coliform ) dan tabel 4 (Hasil Uji Biokimia pada Uji KIA, SIM, LIA dan Citrate).

1. Hasil Pengujian Most Probable Number (MPN) Coliform (Tabel 1,2 dan Gambar 1,2)

2. Hasil Uji Identifikasi Escherichia coli (Tabel 3 dan Gambar 3)

3. Hasil Pewarnaan Gram (Gambar 4)

4. Hasil Uji Biokimia (Tabel 4 dan Gambar 5, $6,7,8)$ 
Tabel 1. Hasil MPN Coliform Uji Praduga Pada Saus Siomai

\begin{tabular}{|c|c|c|c|c|c|}
\hline No & Sampel & $\begin{array}{c}\text { Coliform } \\
(\mathrm{APM} / \mathrm{gr})\end{array}$ & $\begin{array}{c}\text { Coliform } \\
(\mathrm{APM} / 100 \mathrm{gr})\end{array}$ & $\begin{array}{c}\text { Standar } \\
\text { Coliform } \\
\text { (APM/100 gr })\end{array}$ & Keterangan \\
\hline 1 & 2 & 35 & 3500 & 100 & TMS \\
\hline 2 & 3 & 35 & 3500 & 100 & TMS \\
\hline 3 & 4 & 35 & 3500 & 100 & TMS \\
\hline 4 & 5 & 35 & 3500 & 100 & TMS \\
\hline 5 & 6 & 35 & 3500 & 100 & TMS \\
\hline 6 & 7 & 35 & 3500 & 100 & TMS \\
\hline 7 & 8 & 35 & 3500 & 100 & TMS \\
\hline
\end{tabular}

Sumber : Peraturan Kepala Badan Pengawas Obat dan Makanan Republik Indonesia nomor HK. 00.06.1.52.4011 Tahun 2008 Keterangan : APM/gr : Angka Paling Mungkin/gram

TMS : Tidak Memenuhi Syarat

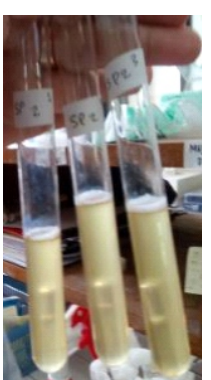

SP 1

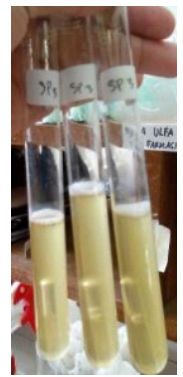

SP 2

SP 3

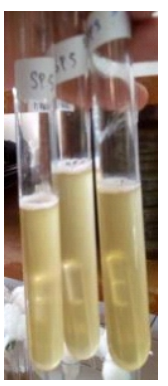

Kontrol Neg tit

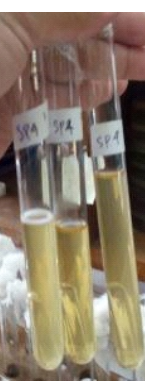

SP 4

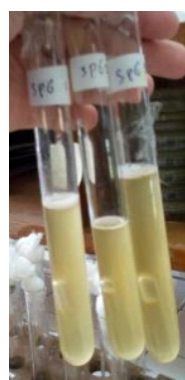

SP 5

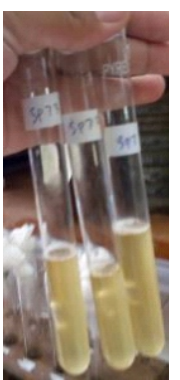

SP 6

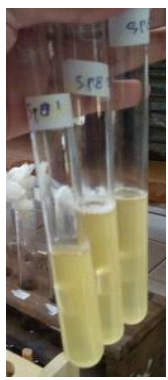

SP 7

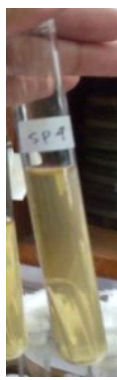

$\mathrm{KN}$

Gambar 1. Hasil MPN Coliform Uji Praduga Pada Saus Siomai

Tabel 2. Hasil MPN Coliform Uji Penegasan Pada Saus Siomai

\begin{tabular}{|c|c|c|c|c|c|}
\hline No & Sampel & $\begin{array}{c}\text { Coliform } \\
\text { (APM/gr })\end{array}$ & $\begin{array}{c}\text { Coliform } \\
\text { (APM/100 gr })\end{array}$ & $\begin{array}{c}\text { Standar Coliform } \\
(\mathrm{APM} / 100 \mathrm{gr})\end{array}$ & Keterangan \\
\hline 1 & 1 & $>1100$ & $>110000$ & 100 & TMS \\
\hline 2 & 2 & $>1100$ & $>110000$ & 100 & TMS \\
\hline 3 & 3 & 9,2 & 920 & 100 & TMS \\
\hline 4 & 4 & $>1100$ & $>110000$ & 100 & TMS \\
\hline 5 & 5 & $>1100$ & $>110000$ & 100 & TMS \\
\hline 6 & 6 & $>1100$ & $>110000$ & 100 & TMS \\
\hline 7 & 7 & $>1100$ & $>110000$ & 100 & TMS \\
\hline
\end{tabular}

Sumber : Peraturan Kepala Badan Pengawas Obat dan Makanan Republik Indonesia nomor HK. 00.06.1.52.4011 Tahun 2008 Keterangan : APM/gr : Angka Paling Mungkin/gram TMS : Tidak Memenuhi Syarat

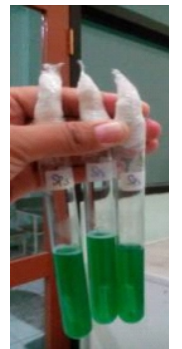

SP 1

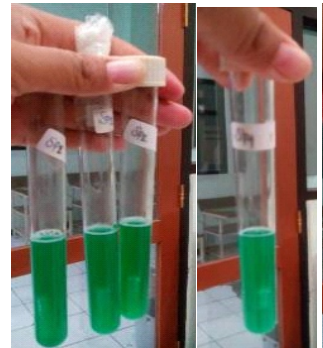

SP 2
SP 3

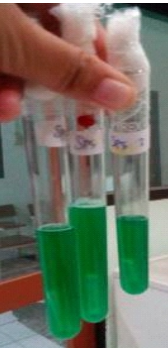

SP 4

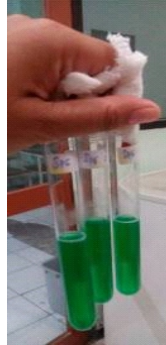

SP 5

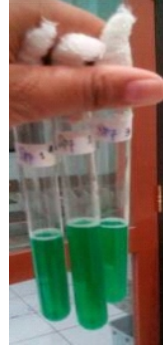

SP 6

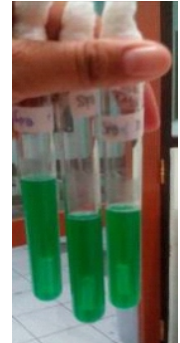

SP 7

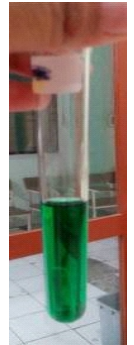

KN

Gambar 2. Hasil MPN Coliform Uji Penegasan Pada Saus Siomai 
Tabel 3. Hasil Identifikasi Coliform

\begin{tabular}{|c|c|c|c|}
\hline No & Sampel & Warna Kultur & Keterangan \\
\hline 1 & 2 & biru kehitaman dengan kilat hijau logam/metalik & + \\
\hline 2 & 3 & biru kehitaman dengan kilat hijau logam/metalik & + \\
\hline 3 & 4 & biru kehitaman dengan kilat hijau logam $/$ metalik & + \\
\hline 4 & 5 & biru kehitaman dengan kilat hijau logam $/$ metalik & + \\
\hline 5 & 6 & biru kehitaman dengan kilat hijau logam $/$ metalik & + \\
\hline 6 & 7 & biru kehitaman dengan kilat hijau logam $/$ metalik & + \\
\hline 7 & 8 & biru kehitaman dengan kilat hijau logam $/$ metalik & + \\
\hline
\end{tabular}

Keterangan : + : Positif Coliform

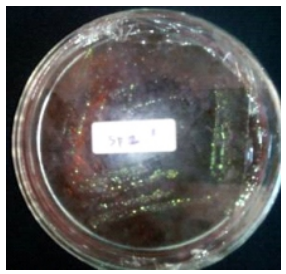

SP 1

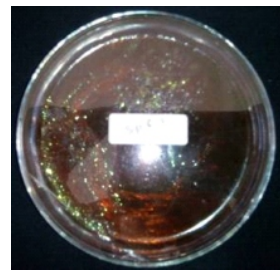

SP 5

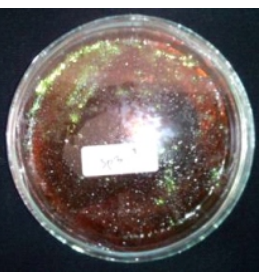

SP 2

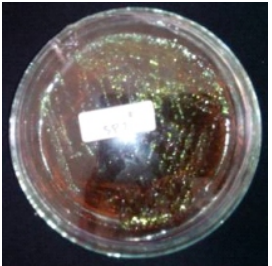

SP 6

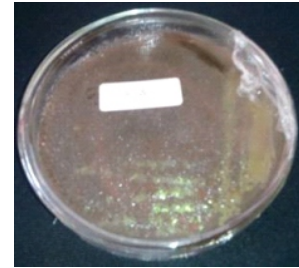

SP 3

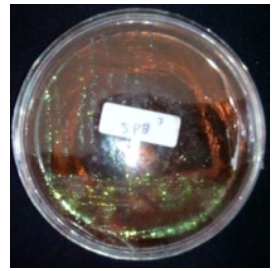

SP 7

Keterangan : SP : Sampel; KN : Kontrol Negatif

Gambar 3. Hasil Identifikasi Coliform

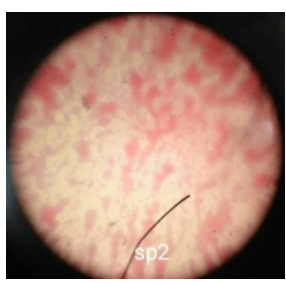

SP 1

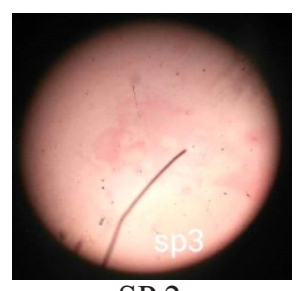

SP 2

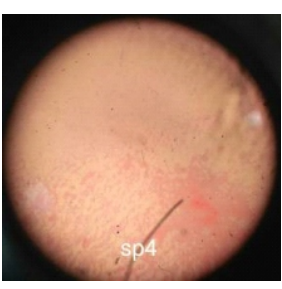

SP 3

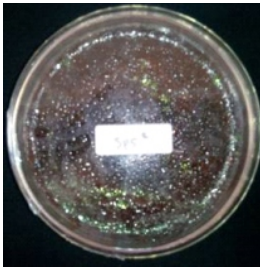

SP 4

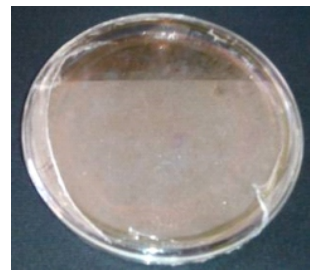

$\mathrm{KN}$

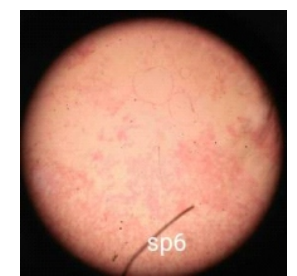

SP 5

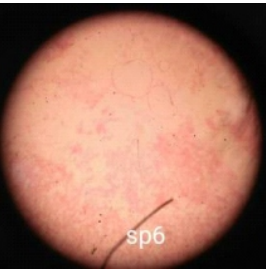

SP 6

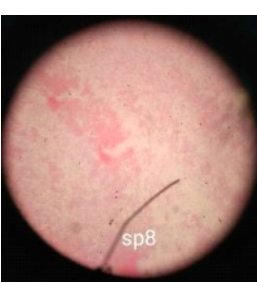

SP 7

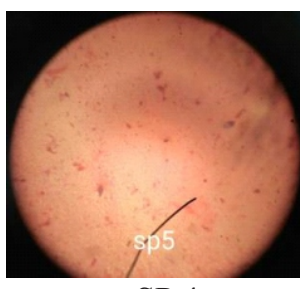

SP 4

Keterangan : SP : Sampel

Gambar 4. Hasil Pengamatan Pewarnaan Gram Bakteri pada Mikroskop

Tabel 4. Hasil Uji Biokimia pada Uji KIA, SIM, LIA dan Citrate

\begin{tabular}{|c|c|c|c|c|c|c|}
\hline No & Sampel & KIA & SIM & LIA & Citrate & Keterangan \\
\hline 1 & 2 & A/AG S- & --+ & A/AG S- & + & Enterobacteria \\
\hline 2 & 3 & A/AG S- & --+ & K/AG S- & + & Enterobacteria \\
\hline 3 & 4 & A/AG S- & -++ & K/A S- & + & Escherichia coli \\
\hline 4 & 5 & A/AG S- & --+ & K/A S- & + & Enterobacteria \\
\hline 5 & 6 & A/AG S- & --+ & K/A S- & + & Enterobacteria \\
\hline 6 & 7 & A/AG S- & --+ & K/A S- & + & Enterobacteria \\
\hline 7 & 8 & A/AG S- & --+ & K/A S- & + & Enterobacteria \\
\hline
\end{tabular}


Keterangan : A/AG S- : atas asam, bawah asam, ada gas, tidak ada sulfida

- + $\quad$ : sulfida tidak ada, indol tidak ada, motilitas ada

$-++\quad$ : sulfida tidak ada, indol positif, motilitas ada

- - $\quad$ : : sulfida, indol dan motilitas tidak ada

A/AG S- : atas asam, bawah asam, ada gas, tidak ada sulfida

K/AG S- : atas basa, bawah basa, ada gas, tidak ada sulfida

K/A S- : atas basa, bawah asam, tidak ada sulfida

$+\quad$ : positif Coliform

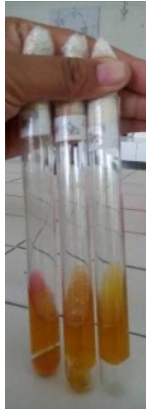

SP 2

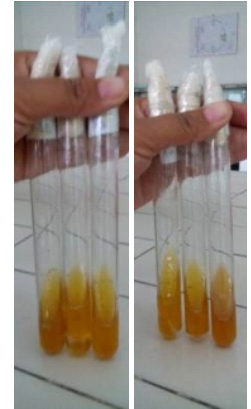

SP 4

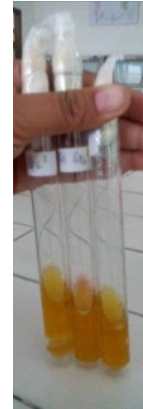

SP 6

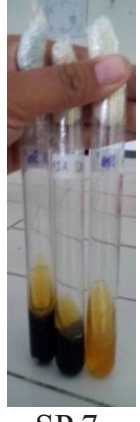

SP 7

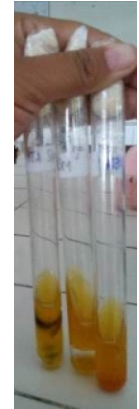

SP 8 Kontrol

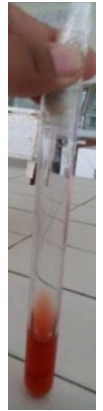

Keterangan : SP : Sampel

Gambar 5. Hasil Uji Biokimia pada Uji KIA

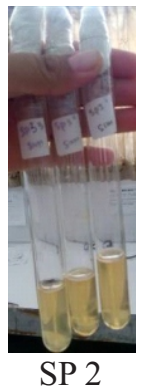

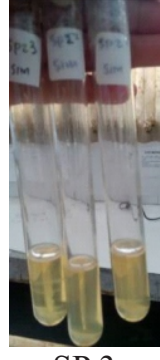

SP 3

: SP : Sam

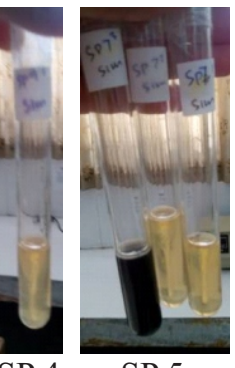

SP 5

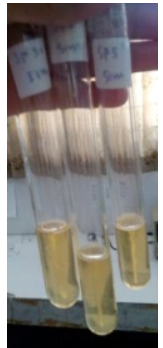

SP 6

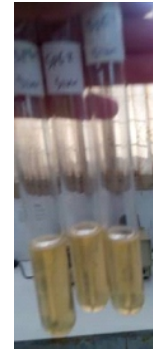

S P 7

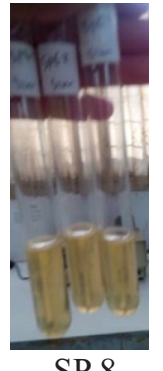

SP 8

Keterangan : SP : Sampel

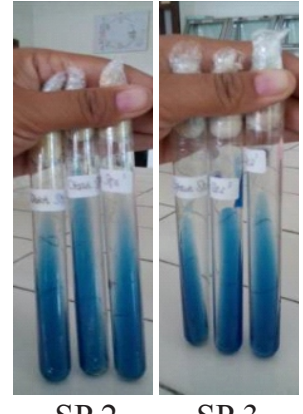

SP 2

Keterangan : SP : Sampel

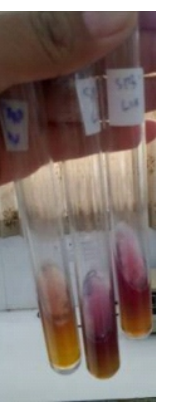

SP 2

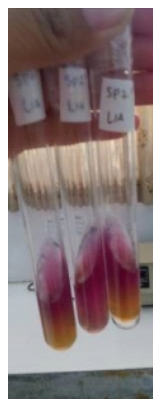

SP 3

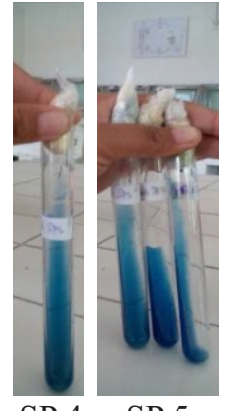

SP 4 SP 5

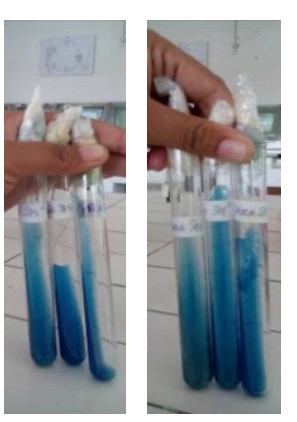

SP 6

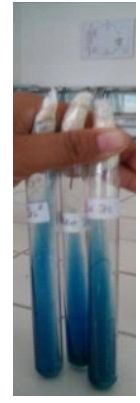

SP 7

Gambar 7. Hasil Uji Biokimia pada Uji Citrate

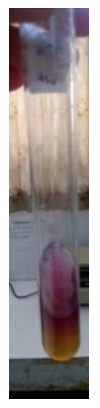

SP 4

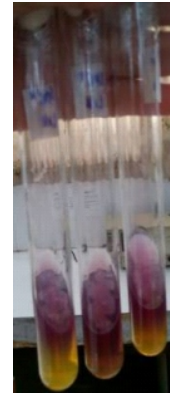

SP 5

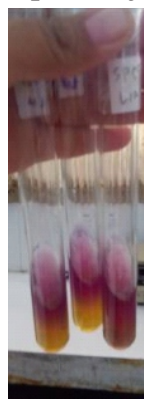

SP 6

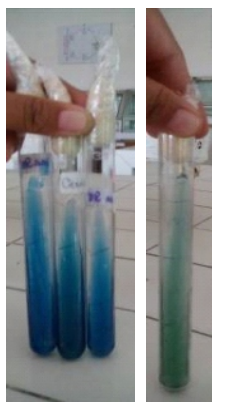

SP 8 Kontrol

Gambar 8. Hasil Uji Biokimia pada Uji LIA 


\section{PEMBAHASAN}

\section{Pengujian Most Probable (MPN) Coliform}

Pengujian MPN menggunakan media Lactose Broth (LB) dan tabung durham. LB merupakan media pembenihan selektif, di dalam media ini mengandung laktosa dan garam empedu (bile salt) yang mengidentifikasi adanya bakeri Coliform yang tumbuh. Coliform adalah kelompok bakteri gram negatif berbentuk batang yang pada umumnya menghasilkan gas jika ditumbuhkan dalam medium laktosa dan terbentuknya asam ditandao dengan perubahan warna biakan menjadi putihatau kuning. Tabung durham digunakan untuk mengetahui adanya pembentukan gas oleh bakteri yang terdapat dalam sampel tersebut. Tahap ini masih merupakan uji presumtif(Cho et al., 2010).

Media yang digunakan untuk mengetahui ada tidaknya kehadiran bakteri coliform (bakteri Gram negatif) berdasarkan terbentuknya asam dan gas yang disebabkan karena fermentasi laktosa oleh bakteri golongan coli. Terbentuknya asam dilihat dari kekeruhan pada media laktosa dan gas yang dihasilkan dapat dilihat dalam tabung durham berupa gelembung udara. Tabung dinyatakan positif coliform jika terbentuk gas sebanyak 10\% atau lebih dari volume di dalam tabung durham (Pertiwi et al., 2016).

Uji konfirmasi digunakan media selektif yaitu Brilliant Green Lactose Bile 2\% (BGLB). Selain mengandung laktosa, BGLB juga mengandung Brilliant Green yang dapat menghambat pertum-buhan bakteri Gram positif.

Berdasarkan Tabel 1 dan 2 di atas menunjukkan bahwa sepuluh (7) saus siomai yang diperiksa mengandung bakteri Coliform yang diperiksa mengandung bakteri Coliform dengan jumlah bakteri Coliform yang tidak memenuhi syarat mutu kesehatan yang tercantum dalam Peraturan Kepala Badan Pengawas Obat dan Makanan Republik Indonesia nomor HK. 00.06.1.52.4011 yaitu maksimal $100 \mathrm{APM} / \mathrm{g}$.
Adanya bakteri Coliform di dalam makanan/minuman menunjukkan kemungkinan adanya mikroba yang bersifat enteropatogenik dan atau toksigenik yang berbahaya bagi kesehatan.

\section{Identifikasi Escherichia coli}

EMBA bersifat selektif differensial dalam menumbuhkan Escherichia coli karena dalam media ini mengandung eosin yang dapat menghambat pertumbuhan bakteri gram positif dan hanya dapat menumbuhkan bakteri gram negatif. Laktosa dan zat pewarna eosin serta metilen blue mampu membedakan antara bakteri yang memfermentasir laktosa dengan nonfermenter. Koloni Escherichia coli tersebut kelihatan biru kehitaman dengan kilat hijau logam/metabolik yang disebabkan besarnya kuantitas asam yang dihasilkan dan pengendapan zat pewarna di atas permukaan pertumbuhan.

Media Eosin Methylene Blue mempunyai keistimewaan mengandung laktosa dan berfungsi untuk memilah mikroba yang memfermentasikan laktosa seperti $S$. aureus, $P$. aerugenosa, dan Salmonella. Mikroba yang mem-fermentasi laktosa menghasilkan koloni dengan inti berwarna gelap dengan kilap logam. Sedangkan mikroba lain yang dapat tumbuh koloninya tidak berwarna. Adanya eosin dan metilen blue membantu mempertajam perbedaan tersebut. Namun demikian, jika media ini digunakan pada tahap awal karena kuman lain juga tumbuh terutama P.aerugenosa dan Salmonella sp. dapat menimbulkan keraguan. Bagaiamana pun media ini sangat baik untuk mengkonfirmasi bahwa kontaminan tersebut adalah E.coli (S.N., 2014).

Agar EMBA merupakan media padat yang dapat digunakan untuk menentukan jenis bakteri coli dengan memberikan hasil positif dalam tabung. EMBA yang menggunakan eosin dan metilen blue sebagai indikator memberikanperbedaan yang nyata antara koloni yang meragikan laktosa dan yang tidak. Untuk me- 
ngetahui jumlah bakteri E.coli umumnya digunakan tabel Hopkins yang lebih dikenal dengan nama MPN (Most Probable Number) atau tabel JPT (jumlah perkiraan terdekat), tabel tersebut dapat digunakan untuk memperki-rakan jumlah

\section{Pewarnaan Gram}

Dari Gambar 4 dapat diketahui bahwa bakteri yang terlihat dari hasil pengamatan di bawah mikroskop adalah bakteri berwarna merah setelah proses pewarnaan. Hal ini disebabkan karena perbedaan struktur dinding sel. Dinding sel bakteri Gram negatif mengandung lipida yang tinggi, sehingga sewaktu pencucian dengan larutan pemucat menyebabkan pembesaran lubang pori-pori dan meningkatkan permeabilitas zat warna. Pencucian menyebabkan kompleks zat warna pertama terlepas. Sedangkan pada dinding sel bakteri Gram positif mengandung lipida rendah, sehingga sewaktu penambahan alkohol terjadi dehidrasi dan pengecilan lubang pori-pori. Hal ini yang menyebabkan zat warna tetap terikat dan sel tetap berwarna ungu (Karlah et al.,2014).

Pada sel Gram-negatif, alkohol meningkatkan porositas dinding sel dengan melarutkan lipid lapisan luar. Oleh sebab itu, efek pencucian alkohol membuat sel-sel menjadi kehilangan warna atau tidak berwarna. Karena hanya sel-sel Gram negatif yang mengalami kehilangan warna sehingga sel-selnya menyerap pewarna tandingan. Sedangkan Gram-positif mempertahankan warna ungu dari pewarna primer (Bambang et al., 2014).

Bakteri Coliform adalah bakteri indikator keberadaan bakteri patogenik lain. Lebih tepatnya, sebenarnya, bakteri Coliform adalah bakteri indikator adanya pencemaran bakteri patogen. Penentuan Coliform menjadi indikator pencemaran dikarenakan jumlah koloninya pas-ti berkorelasi positif dengan keberadaan bakteri patogen. Selain itu, mendeteksi Coliform jauh lebih murah, cepat, dan sederhana daripada mendeteksi bakteri patoge- nik lain (Bambang et al., 2014). Contoh bakteri Coliform adalah Esherichia coli dan Entereobacter aerogenes. Bakteri Coliform menghasilkan zat ethionine yang pada penelitian menyebabkan kanker. Bakteri-bakteri pembusuk ini juga memproduksi bermacammacam racun seperti Indole, skatole yang dapat menimbulkan penyakit bila berlebih di dalam tubuh. Adanya bakteri Coliform di dalam makanan menunjukkan kemungkinan adanya mikroba yang bersifat enteropatogenik dan toksigenik yang berbahaya bagi kesehatan (Aditia dan Muthiadin, 2015).

\section{Uji Biokimia}

Uji biokimia dilakukan dengan uji KIA, SIM, Citrate dan LIA digunakan untuk mengetahui jenis Coliform yang terdapat di dalam sampel. Hasil yang didapatkan menunjukkan semua sampel sampel 1, 2, 4, 5, 6 dan 7 mengandung Enterobacter di dalamnya dan sampel 3 mengandung bakteri Escherichia coli. Pada Uji SIM jika indol menunjukkan hasil positif (ditunjukkan dengan adanya wrana merah) mengandung arti bahwa sampel mengandung Escherichia coli. Hasil uji biokimia dapat dilihat pada Tabel 4.

Uji KIA hasil yang didapatkan adalah $\mathrm{A} / \mathrm{AG}$ S-, A/AG S-, A/AG S-, A/AG S-, A/AG S-, A/AG S-, A/AG S-, yang artinya adalah bahwa pada ketujuh siomai setelah dilakukan uji KI bakteri uji menunjukkan sifat asam yang ditunjukkan dengan warna kuning pada permukaan atas tabung reaksi dan kuning terdapat ruang kosong (berisi gas) pada permukaan bawah tabung reaksi, dan tidak ada sulfida yang ditunjukkan dengan tidak ada warna hitam pada bakteri uji di tabung reaksi. Uji KIA ini digunakan sebagai penguat dalam identifikasi bakteri.

Uji SIM hasil yang didapatkan adalah - - +, - +, - + +, - - +, - - +, - - +, dan - - +. Hasil - - + artinya adalah bahwa tidak ada sulfida pada bakteri uji dalam tabung rekasi yang ditun- 
jukkan dengan tidak adanya warna hitam pada bakteri uji, tidak mengandung indol pada bakteri uji yang dibuktikan dengan tidak adanya warna merah pada bakteri uji dalam tabung reaksi dan terdapat motilitas atau pergerakan dari bakteribakteri dalam tabung reaksi.

Uji LIA hasil yang didapatkan adalah $\mathrm{A} / \mathrm{AG}$ S-, K/AG S-, K/AS-, K/AS-, K/AS-, K/AS- dan K/A S. Tanda A/AG S- artinya adalah setelah dilakukan uji LIA sampel menunjukkan sifat asam yang ditunjukkan dengan warna kuning pada permukaan atas tabung reaksi dan kuning terdapat ruang kosong (berisi gas) pada permukaan bawah tabung reaksi, dan tidak ada sulfida yang ditunjukkan dengan tidak ada warna hitam pada bakteri uji di tabung reaksi. Tanda K/AG S- artinya adalah sampel menunjukkan sifat alkali yang ditunjukkan dengan warna ungu pada permukaan atas tabung reaksi dan kuning terdapat ruang kosong (berisi gas) pada permukaan bawah tabung reaksi, dan tidak ada sulfida yang ditunjukkan dengan tidak ada warna hitam pada bakteri uji di tabung reaksi dan tanda K/A S- artinya adalah sampel menunjukkan sifat alkali yang ditunjukkan dengan warna ungu pada permukaan atas tabung reaksi dan kuning dan tidak terdapat ruang kosong (berisi gas) pada permukaan bawah tabung reaksi, dan tidak ada sulfida yang ditunjukkan dengan tidak ada warna hitam pada bakteri uji di tabung reaksi.

Uji Citrate hasil yang didapatkan adalah ke semua sampel menunjukkan hasil positif yang ditunjukkan dengan warna biru pada tabung rekasi uji. Hasil positif ini menunjukkan bahwa bakteri uji termasuk dalam golongan Coliform. Namun hasil uji citrate ini sifatnya lemah dan yang menentukan kuatnya identifikasi bakteri adalah pada uji KIA.

Bakteri Enterobacter merupakan patogen nosokomial oportunistik yang menyebabkan lebih banyak infeksi termasuk sampai dengan $5 \%$ dari septicemias didapat di rumah sakit, $5 \%$ dari pneumonia nosokomial, 4\% dari infeksi saluran kemih nosokomial, dan 10\% dari kasus peritonitis pascaoperasi. Bakteri ini juga memiliki beberapa kegunaan bagi manusia, namun, misalnya, Enterobacter cloacae digunakan dalam kontrol biologis penyakit tanaman (Anaesthetist) (Zuanita, 2014).

Pencemaran limbah dalam suatu perairan mempunyai hubungan dengan jenis dan jumlah mikroorganisme dalam perairan tersebut. Air buangan kota dan desa yang berpenduduk padat tidak hanya meningkatkan pertumbuhan bakteri koliform akan tetapi juga meningkatkan jumlah bakteri patogen seperti Salmonella, Shigella dan Vibrio cholera (Zuanita, 2014).

Infeksi pada luka mungkin ringan tetapi sering berlanjut dengan cepat (setelah beberapa jam), dengan perkembangan lesi kulit bullous, selulitis, dan miositis dengan nekrosis. Karena cepatnya kemajuan dari infeksi, maka diperlukan pengobatan antibiotik sesuai sebelum konfirmasi dengan kultur didapat. Diagnose didapat melalui kultur organisme pada media laboratorium standar (Khaq et al., 2016).

Escherichia coli mengacu pada sekelompok bakteri yang biasanya ditemukan dalam makanan dan air. Kebanyakan dari bakteri ini tidak berbahaya, tetapi beberapa jenis dapat menyebabkan penyakit. Penyakit akibat E. coli timbul saat bakteri ini melepaskan racun yang dinamakan Shiga sehingga membuat orang sakit. Racun E. coli paling sering menyebabkan masalah perut dan usus, seperti diare dan muntah. Sebagian kecil kasus infeksi bisa mengancam jiwa, sementara penderita yang lain akan pulih setelah sekitar satu minggu. Anakanak, orang-orang dengan gangguan sistem kekebalan tubuh, dan orang tua berada pada risiko tertinggi akibat serangan E. coli (Yunita, 2015).

Strain E. coli yang menimbulkan penyakit hidup dalam usus hewan memamah biak seperti sapi, rusa, dan kambing. E. coli biasanya tidak menyebabkan masalah bagi hewan, tapi ketika kotoran atau sumber air dari hewan yang 
terinfeksi kontak dengan manusia maka infeksi dapat terjadi. Kebanyakan orang yang terinfeksi E. coli mendapatkannya dari makanan yang terkontaminasi, susu yang tidak dipasteurisasi, atau air yang tidak dimasak. Selain hal di atas, daging mentah juga dapat membawa E. coli. E.coli juga dapat menyebar antar manusia melalui kontak dengan kotoran yang terkontaminasi (Yunita, 2015).

Escherichia coli merupakan anggota flora normal usus yang berperan penting dalam sintesis vitamin $\mathrm{K}$, konversi pigmen-pigmen empedu, asam-asam empedu dan penyerapan zat-zat makanan. E. coli termasuk ke dalam bakteri heterotrof yang memperoleh makanan berupa zat organik dari lingkungannya karena tidak menyusun sendiri zat organik yang dibutuhkannya (Adi, 2010). Salah satu strain $E$. coli yang bersifat toonosis adalah seritip 0157 . Manusia dan ternak merupakan reservoir utama E. coli 0157:H7. Air dan makanan yang tercemar oleh kotoran hewan atau manusia yang mengandung E. coli 0157 :H7 berfungsi sebagai sumber infeksi. E. coli 0157:H7 ini dapat menyebabkan diare berdarah yaitu hemolytik uremik syndrome (illes) yang berasal dari makanan. Infeksi E. coli $0157: \mathrm{H} 7$ yang patogen pada manusia yaitu bersifat verotoksigenik yang telah menyebabkan 16.000 kasus penyakit melalui makanan (food borne disease) dan 400 orang meninggal di Amerika. Semakin tinggi tingkat kontaminasi bakteri coliform, semakin tinggi pula risiko kehadiran bakteribakteri patogen lain yang biasa hidup dalam kotoran manusia dan hewan (Bambang et al., 2014).

Hasil analisis menunjukkan bahwa saus siomai tercemar dengan E. coli. Karena tidak dilakukan pemeriksaan di tempat pengolahan maka diperkirakan cemaran tersebut dapat berasal dari pengolah pangan, peralatan yang digunakan maupun lingkungan tempat pengolahan yang tercemar E. coli (Yunita, 2015). Mencuci tangan menggunakan sabun setelah menggunakan kamar kecil, setelah mengolah daging mentah, atau setelah melakukan aktivitas lain dengan potensi terkontaminasi merupakan cara efektif mencegah infeksi $E$. coli. Untuk membunuh $E$. coli dalam makanan, pastikan Anda memasak daging sampai matang. Daging harus dimasak setidaknya sampai suhu $70^{\circ} \mathrm{C}$. Semua piring yang kontak dengan daging mentah sebaiknya dicuci dengan sabun antiseptik. Namun perlu diingat bah-wa seseorang masih dapat terkena E. coli yang berasal dari buah-buahan segar dan sayuran (Cho et al., 2010).

Pada penelitian Djaja (2003) disebutkan bahwa kontaminasi Escherichia coli pada pedagang kaki lima disebabkan karena kontaminasi bahan makanan $(51,8 \%)$, kontaminasi pewadahan (18,8\%), kontaminasi air $(18,8 \%)$, kontaminasi makanan disajikan $(18,8 \%)$, kontaminasi tangan (12,9\%) dan kontaminasi makanan matang (10,6\%). Dalam hal ini, terjadinya kontaminasi Escherichia coli pada pasar tradisional dan swalayan dapat disebabkan oleh hal di atas.

Sanitasi yang kurang baik dari penjamah makanan atau penjual dapat menjadi sumber penyakit bagi konsumen dan dapat menyebar kepada masyarakat. Peranannya dalam suatu penyebaran penyakit dengan cara kontak antara penjamah makanan yang menderita penyakit menular dengan konsumen yang sehat (Kim dan Kim, 2012). Kontaminasi terhadap makanan oleh penjamah makanan yang sakit, misalnya batuk atau luka di tangan, dan pengolahan makanan dengan air tercemar Escherichia coli atau penanganan makanan oleh penjamah makanan yang sakit atau pembawa kuman (Zaenab, 2008).

Beberapa penyakit yang sering timbul akibat bakteri Escherichia coli adalah penyakit diare, bakteri Escherichia coli yang menyebabkan diare sangat sering ditemukan diseluruh dunia. Bakteri ini diklasifikasikan oleh ciri khas sifatsifat virulensinya dan setiap grup menimbulkan penyakit melalui mekanisme yang berbeda 
seperti yang sudah diutarakan. Gejalanya yaitu diare yang merupakan buang air besar yang encer dengan frekuensi $4 \mathrm{x}$ atau lebih dalam sehari, kadang disertai muntah, badan lesu atau lemah, panas, tidak nafsu makan, bahkan darah dan lendir dalam kotoran. Diare bisa menyebabkan kehilangan cairan dan elektrolit sehingga bayi menjadi rewel atau terjadi gangguan irama jantung maupun perdarahan otak (Falamy et al., 2012).

Infeksi saluran kemih, penyebab yang paling sering dari infeksi saluran kemih dan merupakan penyebab infeksi saluran kemih pertama pada kira-kira $90 \%$ wanita muda. Gejalanya yaitu sering kencing, disuria, hermaturia, dan piura. Kebanyakan infeksi ini disebabkan oleh Escherichia coli dengan sejumlah tipe antigen $\mathrm{O}$. Sepsis, bila pertahanan tubuh ibu tidak kebal, Escherichia coli dapat memasuki aliran darah dan menyebabkan sepsis. Meningitis, Escherichia coli merupakan salah satu penyebab utama meningitis pada bayi. Bakteri Escherichia coli dari kasus meningitis ini mempunyai antigen KI. Mekanisme virulensi yang berhubungan dengan antigen $\mathrm{KI}$ tidak diketahui (Tambunan, 2010).

Hasil penelitian ini menunjukkan bahwa Pemerintah dan Pemerintah Daerah bersama dengan instansi yang terkait masih perlu melakukan pengawasan makanan terhadap saus tomat yang banyak dikonsumsi masyarakat sesuai dengan pasal 68 UU No. 18 Tahun 2012 tentang Pangan. Pengawasan makanan, seperti pada saus tomat bertujuan untuk melindungi masyarakat konsumen terhadap kemungkinan peredaran makanan yang tidak memenuhi standar dan persyaratan kesehatan yang dapat merugikan atau membahayakan kesehatan. Hal ini serupa juga dengan hasil penelitian Nadifah et al. (2014) meskipun sampel diambil dari satu pasar tradisional di Sleman, namun merek saus tomat yang diperiksa adalah saus tomat yang beredar di Yogyakarta. Hasil penelitian ini dapat memberikan gambaran tentang kontaminasi bakteri pada saus tomat.

\section{KESIMPULAN}

Berdasarkan hasil penelitian yang dilakukan pada saus siomai, maka diperoleh kesimpulan sebagai berikut :

a. Sampel 2, 3, 4, 5, 6, 7 dan 8 positif mengandung bakteri Coliform dengan MPN Coliform tertinggi pada sampel 2 dan 8 yaitu $>1100 \mathrm{APM} / \mathrm{g}$ dan terendah adalah sampel 6 dan 10 yaitu 210 APM/g.

b. Sampel 2, 3, 5, 6, 7 dan 8 positif mengandung bakteri Enterobacter dan sampel 4 mengandung bakteri Escherichia coli.

c. Dari hasil pewarnaan gram pada sampel 2, 3, 4, 5, 6, 7 dan 8 semua bakteri termasuk golongan bakteri gram negatif.

d. Hasil pengujian yang didapat dari semua uji ALT dan MPN Coliform tidak memenuhi syarat yang telah ditetapkan dalam SNI 013546-2004 tentang batas maksimum Angka Lempeng Total (ALT) pada saus tomat adalah $2 \times 10^{2}$ koloni/g sedangkan menurut Peraturan Kepala Badan Pengawas Obat dan Makanan Republik Indonesia nomor HK. 00.06.1.52.401, batas maksimum Most Probable Number (MPN) Coliform pada saus tomat adalah $100 \mathrm{koloni} / \mathrm{g}$.

\section{UCAPAN TERIMA KASIH}

Penulis ucapkan terima kasih kepada Direktorat Penelitian dan Pengabdian Kepada Masyarakat sesuai dengan Surat Perjanjian Pelaksanaan Penugasan Penelitian Dosen Pemula Bagi Dosen Perguruan Tinggi Swasta Antara Direktorat Riset dan Pengabdian Masyarakat Direktorat Jenderal Penguatan Riset dan Pengembangan Kementerian Riset, Teknologi dan Pendidikan Tinggi dengan Kopertis Wilayah VI Nomor 048/K6/SP2H/PPM/2017, tanggal 21 April 2017 dan Antara Kopertis Wilayah VI dengan Apikes Citra Medika Surakarta Nomor: 089/K6/SP2H/ 
PENELTIAN/2017. Penulis juga ucapkan terima kasih kepada Ketua yayasan Internusa dan Direktur Apikes Citra Medika Surakarta yang telah memberikan izin penelitian dan juga kepada UPT Laboratorium Terpadu UNS yang telah memberikan izin penelitian.

\section{DAFTAR PUSTAKA}

Aditia, Lasinrang dan Muthiadin, Cut. 2015. Uji Kualitas Mikrobiologis Pada Makanan Jajanan di Kampus II Universitas Islam Negeri (UIN) Alauddin Makassar. Biogenesis. Vol 3, No. 2 hal 119-123. ISSN 2302-1616.

Bambang, Andrian G; Fatimawali dan Kojong, Novel S. 2014. Analisis Cemaran Bakteri Coliform Dan Identifikasi Escherichia coli Pada Air Isi Ulang Dari Depot Di Kota Manado. Pharmacon. Vol. 3 No. 3. ISSN 2302-2493.

BPOM RI. 2008. Pengujian Mikrobiologi Pangan. InfoPOM. Vol. 9, No. 2. ISSN 1829-9334.

Cho, Joon-Il; Cheung, Chi-Yeun; Lee, Sun-Mi; Ko, Soo-Il; Kim, Kyu-Heon; Hwang, In-Sun; Kim, Seung-Hwan; Cho, SooYeol, Lim, Chul-Ju; Lee, Kwang-Ho; Kim, Keun-Sung And Ha, Sang-Do. 2010. Assessment Of Microbial Contamination Levels Of Street-Vended Foods In Korea. Journal of Food Safety 31 (2011) 41-47.

Cut Nuria, Maulita, dkk. 2009. Uji Kandungan Bakteri Escherichia Coli Pada Air Minum Isi Ulang Dari Depot Air Minum Isi Ulang Di Kabupaten Rembang. Jurnal-Jurnal Ilmu Pertanian. Volume 5 no (1) hal 27-35.

Djaja. I.M. 2003. Kontaminasi E. coli pada makanan dari tiga jenis tempat pengelolaan makanan (TPM) di jakarta selatan. Jurnal Makara Kesehatan Vol. 12. Hal. 36-41.

Falamy, Ryan; Warganegara, Efrida dan Apriliana, Ety, 2012. Deteksi Bakteri Coliform pada Jajanan Pasar Cincau Hitam di Pasar Tradisional dan Swalayan Kota Bandar Lampung. Majority (Medical Journal Of Lampung University). ISSN 2337-3776.

Imelda Gea, Santi. 2009. Hygiene Sanitasi dan Analisa Cemaran Mikroba yang Terdapat Pada Saus Tomat dan Saus Cabai Isi Ulang yang Digunakan di Kantin di Lingkungan Universitas Sumatera Utara. Skripsi. Universitas Sumatera Utara.

Karlah, L. R. Mansauda; Fatimawali dan Novel, Kojong. 2014. Analisis Cemaran Bakteri Coliform Pada Saus Tomat Jajanan Bakso Tusuk Yang Beredar Di Manado. Jurnal Ilmiah Farmasi. UNSRAT. Volume 3 no (2) hal

Kartika, Emma, Siti Khotimah, Ari Hepi Yanti. 2014. Deteksi Bakteri Indikator Keamanan Pangan Pada Sosis Daging Ayam Di Pasar Flamboyan Pontianak. Probiont. Volume 3, 2:111-119.

Khaq, Khanifa Nurul dan Dewi, Lusiawati. 2016. Deteksi Cemaran Bakteri Koliform Dan Salmonella Sp. Pada Tempe Yang Dikemas Daun Pisang Di Daerah Salatiga. Agric. Vol. 28, No. 1 dan No.2, Juli \& Desember 2016: 79 86.

Kusumaningsih, Anni. 2010. Beberapa Bakteri Patogenik Penyebab Foodborne DiseasePada Bahan Pangan Asal Ternak. Makalah Balai Besar Penelitian Veteriner Bogor hal 103-111.

Laboratorium Mikrobiologi. 2017. Surakarta : Universitas Setia Budi.
Lesmana, M. 2003. Enterobacteriaceae: Salmonella \& Shigella. FK Universitas Trisakti, Jakarta.

Lestari, Rina. 2012. Pewarnaan Sederhana, Negatif, Kapsul dan Gram. Makalah. Sekolah Tinggi Ilmu Kesehatan Yogyakarta.

Nadifah, Fitri; Bhoga, Maria Yashita dan Presetyaningsih, Yuliana. 2014. Kontaminasi Bakteri Pada Saus Tomat Mie Ayam di Pasar Condong Catur Sleman Yogyakarta Tahun 2013. Biogenesis. Vol 2, No. 1, Juni 2014, hal 30-33. ISSN 2302-1616.

Notoatmodjo, S. 2003, Pendidikan dan Perilaku Kesehatan. Jakarta: Rineka Cipta.

Pertiwi, Devi Pebriani; Latifa, Roimil, Dan Chamisjiatin, Lise. 2016. Analisis Kandungan Bakteri Koliform Pada Bakso Bakar Di Pasar Minggu Kota Malang. Prosiding Seminar Nasional II Tahun 2016, Kerjasama Prodi Pendidikan Biologi FKIP Dengan Pusat Studi Lingkungan Dan Kependudukan (PSLK) Universitas Muhammadiyah Malang.

Rompre, Annie; Servais, Pierre, Baudart, Julia; Roubin, MarieRene'e de- and Laurent, Patrick. 2001. Detection and enumeration of coliforms in drinking water: current methods and emerging approaches. Journal of Microbiological Methods 49 (2002) 31-54.

S. N., Madueke, S. Awe And A. I., Jonah. 2014. Microbiological Analysis Of Street Foods Along LokojaAbuja Express Way, Lokoja. American Journal of Research Communication Vol 2(1).

Siagian, A. 2002. Mikroba Patogen Pada Makanan dan Sumber Pencemarannya. SNI 01-3546-2004. Saus Tomat. Jakarta : Dewan Standarisasi Nasional.

Siahaya, Griennasty Clawdya. 2016. Total Mikroba Dan Escherichia coli Pada Pangan Jajanan. 2-TRIK: TunasTunas Riset Kesehatan. Volume VI Nomor 4, November 2016 ISSN: 2089-4686.

Sunardi. 2014. Pemeriksaan Most Probable Number (MPN) Bakteri Coliform Dan Coli Tinja Pada Jamu Gendong Yang Dijual Di Pasar Besar Kota Palangkaraya. Karya Tulis Ilmiah. Program Studi D III Farmasi Universitas Muhammadyah Palangkaraya.

Susanna, D, Hartono, B. 2003. Pemantauan Kualitas Makanan Ketoprak Dan Gado-Gado Di Lingkungan Kampus UI Depok, Melalui Pemeriksaan Bakteriologis. FKM UI, Depok.

Tambunan, Samuel. 2010. Hygiene Sanitasi dan Pemeriksaan Kandungan Bakteri. Escherichia coli pada Es Kolak Durian yang Dijajakan Di Jalan Dr. Mansyur Kelurahan Padang Bulan Kota Medan Tahun 2010. Skripsi FKM. USU Medan.

Wang, Y. Ye. 2011. Substractive Inhibition Assayfor the Detection of Escherichia coli 0157:H7 Using Surface Plasmon Resonance. Sensors. 2011 (11): $2728: 2739$.

Yunita, Nur Halimah. 2015. Identifikasi Dan Karakterisasi Bahaya Bakteri Patogen Pada Pangan Jajanan Anak Sekolah Di Bogor. Tesis. Bogor : Institut Pertanian Bogor.

Zaenab. 2008. Kasus Keracunan Makanan. Kesehatan Lingkungan Makassar.

Zuanita, Dwi Astalia; Suarjana, I Gusti Gusti dan Rudyanto, Mas Djoko. 2014. Cemaran Coliform pada Daging Ayam Pedaging yang Dijual di Swalayan di Denpasar. Indonesia Medicus Veterinus. 3(1) :26-31 ISSN : 2301-7848. 